\title{
Comparison of the performances of two commercial membranes in hardness removal from underground water using Nanofiltration membranes
}

\author{
F. Elazhar ${ }^{1 *}$, R. EL Habbani ${ }^{1}$, M. Elazhar ${ }^{1}$, M.Hafsi ${ }^{2}$, and A. Elmidaoui ${ }^{1}$ \\ ${ }^{1}$ Laboratory of Separation Processes, Department of Chemistry, University Ibn Tofail, BP 1246 Kènitra, Morocco \\ ${ }^{2}$ National office of drinking water and electricity (ONEE), Rabat,Morocco \\ Phonelfax: + 212537373033 \\ *Corresponding author E-mail: azh80ar@yahoo.fr
}

\begin{abstract}
In this study, the comparison of the performances of two commercial membranes in hardness removal by nanofiltration in continuous mode was investigated from synthetic ground water of Maâmoura doped for various concentrations of TH $\left(\mathrm{CaCl}_{2}, \mathrm{MgCl}_{2}\right)$.

The experiments were carried out in the pressure range of 6-40 bars. Analyses of the samples, and permeates at different pressures, were performed and the effects of the trans-membrane pressure on the permeate flux and salt rejections were studied. Also the study presents the effect of salinity of the performances of two tested membranes (NF90 and NF270).

Many configurations were tested: simple pass, double pass with one type of membranes and combination of two types of membranes. The pilot used (supplied by the French Company TIA) is an industrial nanofiltration pilot plant having two modules equipped with various spiral commercial membranes with an area of $7.6 \mathrm{~m}^{2}$.
\end{abstract}

Keywords: Hardness, Nanofiltration, Pressure, Configuration, Simpl pass, Double pass.

\section{Introduction}

Water hardness is due to presence of divalent ions like calcium and magnesium. The hardness of the water poses many problems when water use, such as a disabling washing, formation of tartar carbonate and magnesium hydroxide in the pipe network of hot water $[1,2]$.

The traditional processes for water softening include lime-soda and ion exchange processes. Membrane softening is becoming an alternative to these processes. Nanofiltration process with charged membranes can be used for this purpose $[3,4]$.

A nanofiltration membrane is types of pressure-driven membranes that has properties in between those of ultrafiltration and reverse osmosis membranes. Nanofiltration membranes have the advantages of providing a high water flux at low operating pressure and maintaining a high salt and organic matter rejection rate [5]. The nanofiltration process has the benefits of ease of operation, reliability and comparatively low energy consumption [6] as well as highly efficient pollutant removal. This helps to minimize scale formation on the equipment involved in both reverse osmosis and thermal desalination processes. Therefore, nanofiltration membranes have received interest worldwide.

Schaep et al. [7] studied the reduction in hardness in groundwater achieved by nanofiltration membranes. In their experiments, a cross-flow filtration cell containing flat sheet membranes was used. They studied three commercial nanofiltration membranes and concluded that the performance of the UTC20 nanofiltration membrane for reducing hardness was better than that of the NF70 and UTC60 nanofiltration membranes. At 10 bar transmembrane pressure the calcium retention for UTC20 nanofiltration was $96 \%$.

Gorenflo et al. [8] examined the nanofiltration of German groundwater with high hardness and natural organic matter (NOM) content. They used NF200B nanofiltration with 5.5 bar transmembrane pressure and a water recovery rate between $60 \%$ and $85 \%$. Their results showed almost complete rejection (>95\%) of NOM. Due to the high concentration of $\mathrm{SO}_{4}{ }^{2-}$ present and presumably due to the complexation of $\mathrm{Ca}^{2+}$ with humic substances, the rejection of $\mathrm{Ca}^{2+}$ and $\mathrm{Mg}^{2+}$ was unexpectedly high ( $74 \%$ and $>86 \%$, respectively) compared to a pure $\mathrm{CaCl}_{2}$ solution $(\mathrm{R}(\mathrm{CaC} 1) \sim 45 \%)$. 
Ghizellaoui et al. [9] studied the softening of drinking water of Constantine (Algeria), city supplied by underground and surface water using NanoMax-50 nanofiltration membranes. They studied the effects of pressure, flow rate and temperature on the nanofiltration performance. The maximum transmembrane pressure was 2 bars. The results indicated that the retention of both cations and anions increased with the applied pressure. The retention of divalent cations $\left(\mathrm{Ca}^{2+}\right.$ and $\mathrm{Mg}^{2+}$ ) was higher than that of monovalent cations $\left(\mathrm{Na}^{+}\right.$and $\left.\mathrm{K}^{+}\right)$.

Recently Galanakis et al. [10] performed nanofiltration of brackish groundwater by using a poly-piperazine membrane. They used cross flow nanofiltration module and low transmembrane pressure (6-10 bar). Their samples have hardness and salinity values up to $762 \mathrm{mg} \mathrm{CaCO}_{3}$ and $1,803 \mathrm{mg} \mathrm{NaCl} / \mathrm{L}$, respectively. Their results showed that this nanofiltration membrane could remove $70-76 \%$ of hardness and $44-66 \%$ of salinity.

In previous studies, Elazhar et al $[11,12]$ investigate the technical and economical performances of the nanofiltration process for desalination of brackish groundwater with salinity is about $3 \mathrm{~g} / \mathrm{l}$ and to compare these results with reverse osmosis process. According to the results, the nanofiltration membrane might be able to produce a satisfactory quality water with high permeate quality and low costs compared to reverse osmosis membrane.

Therefore, the aim of this works is to study the performances of two nanofiltration membranes (NF90 and NF270) in hardness removal from ground water of Maâmoura. In this context, various concentrations of $\mathrm{TH}\left(\mathrm{CaCl}_{2}, \mathrm{MgCl}_{2}\right)$ were investigated and many configurations were tested: simple pass and double pass with combination. The water parameters were followed as a function of the running conditions (salinity, pressure) in order to follow the behavior of the membranes tested.

\section{Experimental part}

\subsection{Brackish groundwater}

The Nanofiltration operations were conducted for an underground water of Maâmoura doped for the three concentrations of $\mathrm{TH}\left(\mathrm{CaCl}_{2}, \mathrm{MgCl}_{2}\right),\left(\mathrm{FW} 1=80\left({ }^{\circ} \mathrm{F}\right)\right)$, $\left(\mathrm{FW} 2=100\left({ }^{\circ} \mathrm{F}\right)\right),\left(\mathrm{FW} 3=150\left({ }^{\circ} \mathrm{F}\right)\right)$. Table 1 gives the characteristic of brackish groundwater and the Moroccan standards of drinking water.

Table 1: Characteristics of the feed water

\begin{tabular}{|l|c|c|c|c|}
\hline & \multicolumn{1}{|l|}{ FW1 } & \multicolumn{1}{l|}{ FW2 } & FW3 & $\begin{array}{c}\text { Moroccan standards of } \\
\text { drinking water }\end{array}$ \\
\hline $\mathrm{TH}\left(\mathrm{CaCl}_{2}, \mathrm{MgCl}_{2}\right)\left({ }^{\circ} \mathrm{F}\right)$ & 80 & 100 & 150 & ----- \\
\hline $\mathrm{pH}$ & 6.70 & 6,98 & 6.73 & $6.50-8.50$ \\
\hline Turbidity $(\mathrm{NTU})$ & 0,50 & 0,92 & 1,02 & $<5$ \\
\hline Conductivity $(\mu \mathrm{S} / \mathrm{cm})$ & 1793 & 2200 & 3050 & $<1000$ \\
\hline TDS $(\mathrm{ppm})$ & 1344,75 & 1650 & 2287,5 & 500 \\
\hline $\mathrm{Hardness}\left({ }^{\circ} \mathrm{F}\right)$ & 108.34 & 136.24 & 198.4 & 50 \\
\hline $\mathrm{Ca}^{2+}(\mathrm{ppm})$ & 278.4 & 339.2 & 435.2 & $<270$ \\
\hline $\mathrm{Mg}^{2+}(\mathrm{ppm})$ & 7.68 & 10.24 & 17.92 & $<50$ \\
\hline $\mathrm{Na}^{+}(\mathrm{ppm})$ & 56,40 & 56,40 & 56,40 & 250 \\
\hline $\mathrm{SO}_{4}{ }^{2-}(\mathrm{ppm})$ & 60 & 60 & 60 & 200 \\
\hline $\mathrm{Cl}^{-}(\mathrm{ppm})$ & 541.38 & 665.63 & 1020.63 & 250 \\
\hline $\mathrm{NO}_{3}^{-}(\mathrm{ppm})$ & 41 & 41 & 41 & 50 \\
\hline
\end{tabular}

\subsection{Nanofiltration pilot plant}

Nanofiltration (NF) experiments were performed on an industrial pilot NF / RO (E3039) provided by the company TIA (Applied Industrial Technologies, France) figure 1. The applied pressure over the membrane can be varied from 5 to 70 bars with manual valves. The pilot is equipped with two identical modules in series. The pressure drop $\Delta \mathrm{P}$ is about 2 bars. The two spiral wound modules are equipped with two commercial reverse osmosis and nanofiltration membranes. Table 2 gives the characteristics of the used membranes. 


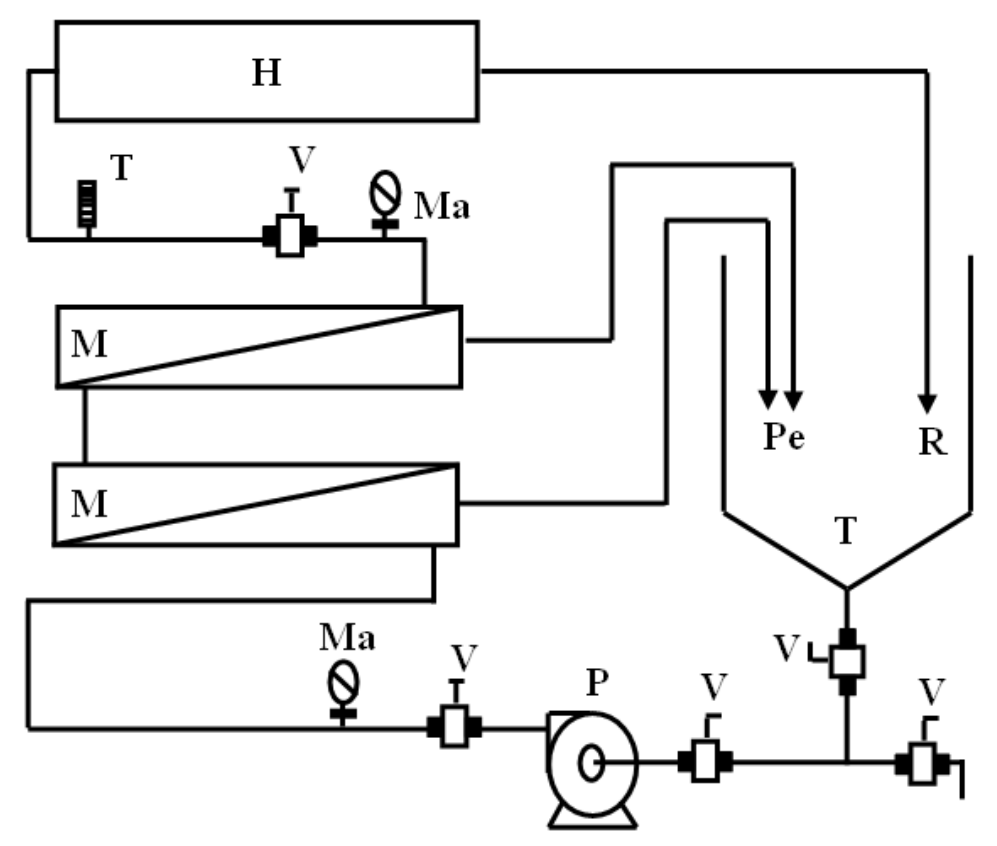

Figure 1: Diagram of the NF/RO pilot plant

$\mathrm{T}$ : tank; P : feed pump; Ve : pressure regulation valves; V : drain valves; $\mathrm{M}: \mathrm{NF} / \mathrm{RO}$ module; Pe : Permeate recirculation; R : Retentate recirculation; H : Heat exchanger; Ma : Pressure sensor; Te : Temperature sensor.

Table 2: Characteristics of the tested membranes

\begin{tabular}{lllll}
\hline Type of membrane & Max pressure & Surface $\left(\mathrm{m}^{2}\right)$ & Tmax $\left({ }^{\circ} \mathrm{C}\right)$ & $\begin{array}{l}{\left[\mathrm{Cl}_{2}\right] \text { tolerance }} \\
\mathrm{ppm}\end{array}$ \\
\hline NF90 $40 * 40$ & 40 bars & 7.6 & $45{ }^{\circ} \mathrm{C}$ & $0.1 \mathrm{ppm}$ \\
NF270 $40 * 40$ & 40 bars & 7.6 & $45{ }^{\circ} \mathrm{C}$ & $0.1 \mathrm{ppm}$ \\
\hline
\end{tabular}

\subsection{Parameters analysis}

The followed parameters were $\mathrm{pH}$, Conductivity (Cond), TDS, TH, $\mathrm{Ca}^{2+}, \mathrm{Mg}^{2+}, \mathrm{Na}^{+}, \mathrm{SO}_{4}^{2-}, \mathrm{Cl}^{-}, \mathrm{NO}_{3}^{-}$, and the Langelier index.

The analysis of the taken sample was carried out following methods described in $[13,14]$.

The permeate volumetric flux (Jv): was determined by measuring the volume of the permeate or the concentrate in a given time interval by the followed relation:

$$
J_{V}=\frac{\Delta V}{\Delta t \times S}
$$

Jv: Flux $\left(\mathrm{L} \cdot \mathrm{h}^{-1} \cdot \mathrm{m}^{-2}\right)$,

$\Delta \mathrm{V}$ : volume of the permeate in a given time interval $(\Delta \mathrm{t})$,

$\mathrm{S}$ : the membrane surface area $\left(\mathrm{m}^{2}\right)$.

- Recovery rate (Y\%) which is defined as:

$Y(\%)=\frac{Q_{p}}{Q_{0}} \times 100$

Where:

$\mathrm{Q}_{\mathrm{p}}$ : permeate flow $(1 / \mathrm{h})$,

$\mathrm{Q}_{0}$ : Feed flow $(\mathrm{l} / \mathrm{h})$.

- The salt rejection $(\mathrm{R} \%)$ which are defined as: 
$R(\%)=\left(1-\frac{C_{p i}}{C_{0 i}}\right) * 100$

Where:

$\mathrm{C}_{\mathrm{Pi}}$ : permeate concentrations,

$\mathrm{C}_{0 \mathrm{i}}$ : initial concentrations.

\section{Results and discussion}

In this work, the performances of nanofiltration membranes in hardness removal are compared for various running conditions of the pilot plant. The influences on permeate water quality of pressure, salinity are followed for the two tested membranes.

\subsection{Effect of pressure}

The experiments were carried out in simple pass configuration. The imposed pressures were: 10,25 and 40 bar for NF90 and 6, 10, and 25 bars for NF270 following the constructor instructions (table 2). The tested water was FW1, FW2, and FW3. Figures 2, 3 and 4 give the influence of the pressure on the permeate volumetric flux and recovery rate for each feed water.
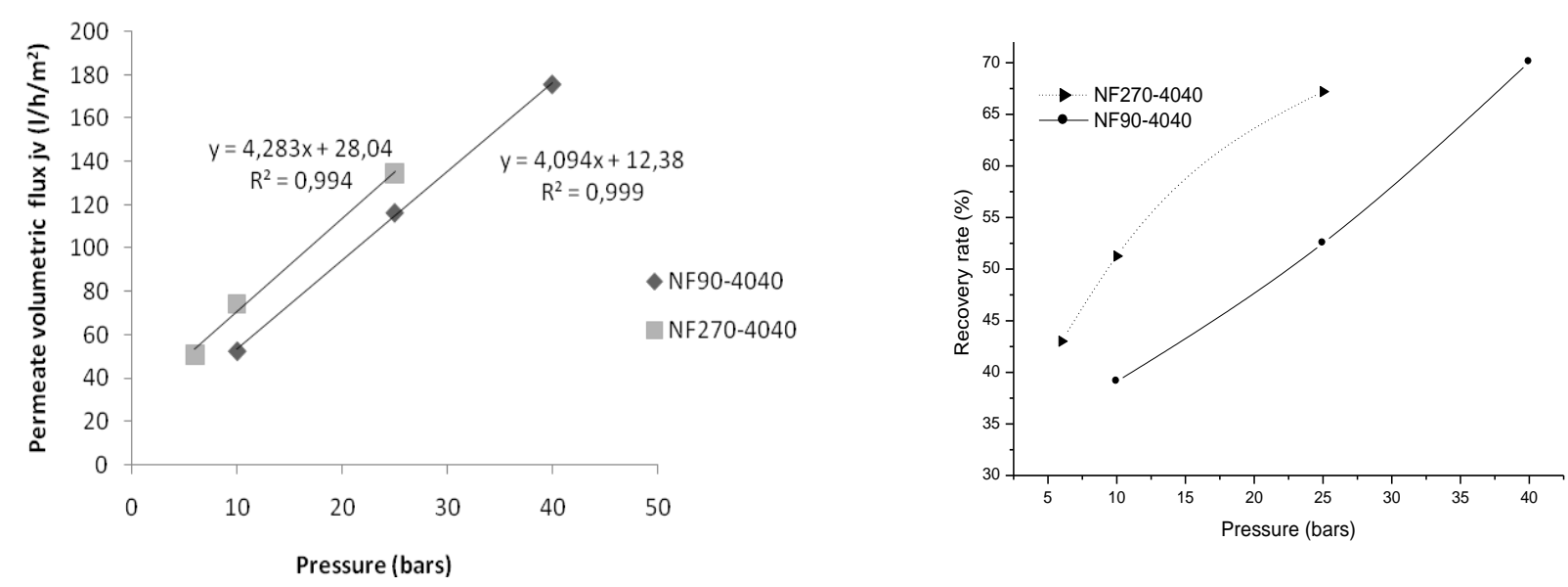

Figure2: Variation of the permeate volumetric flux and recovery rate versus applied pressure of the FW1
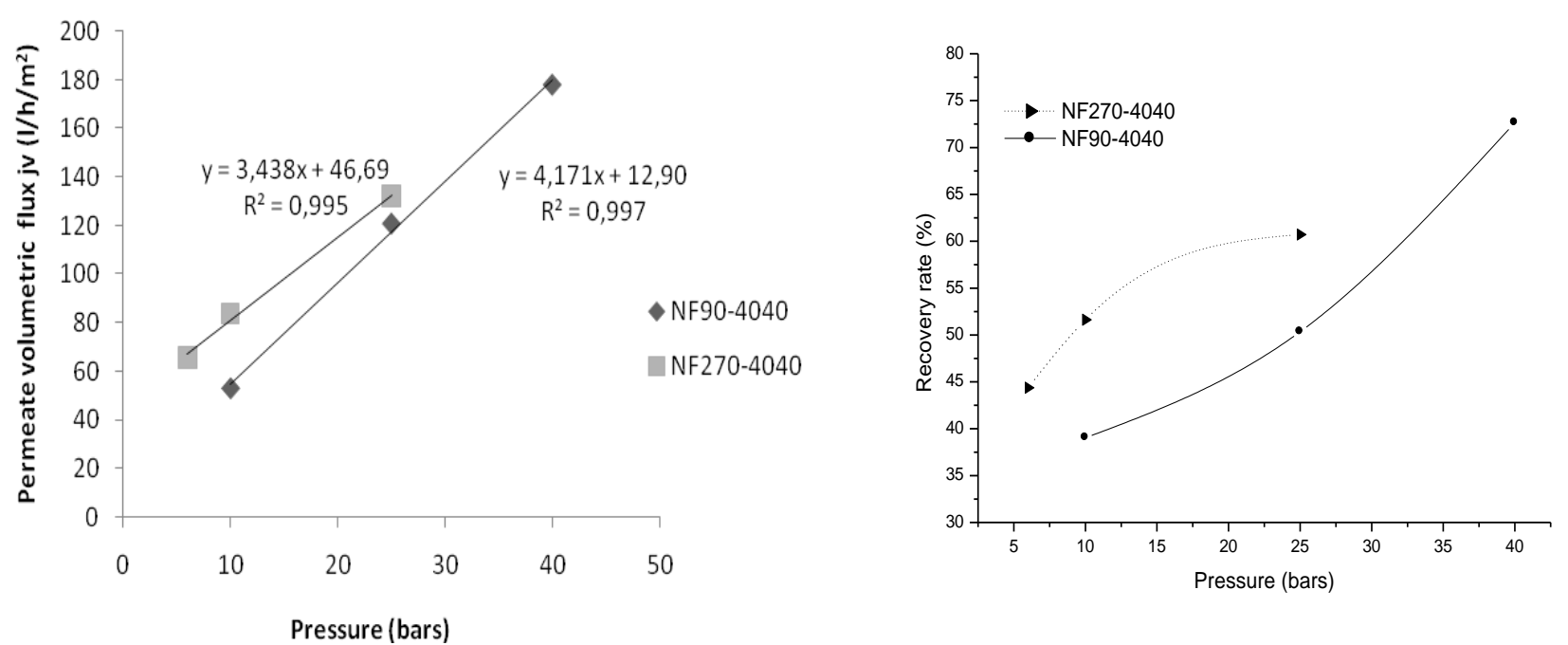

Figure 3: Variation of the permeate volumetric flux and recovery rate versus applied pressure of the FW2 

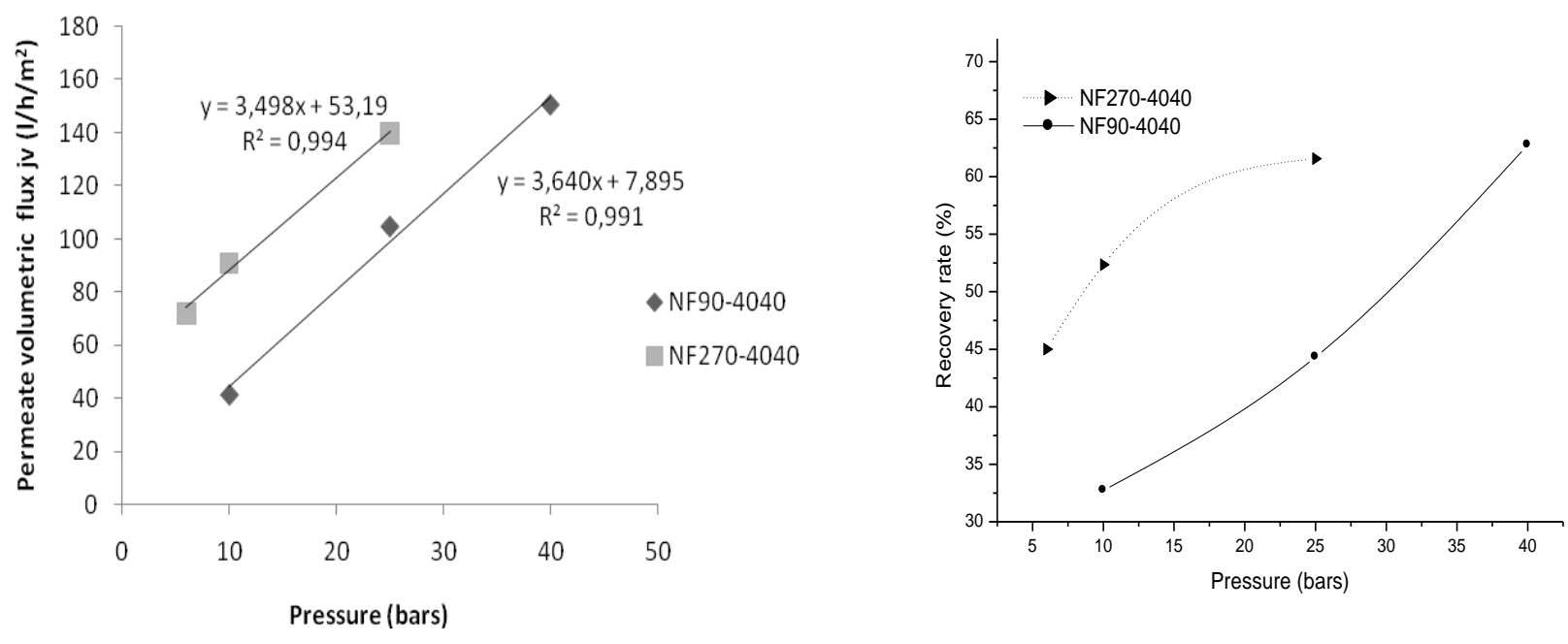

Figure 4: Variation of the permeate volumetric flux and recovery rate versus applied pressure of the FW3

For each tested concentrations, the results show that the volumetric permeate flux increases linearly with the pressure. As earlier observed in this figure, the permeate fluxes obtained by the NF270 is higher than the NF90 membrane. Nevertheless, the recovery rate of NF270 is higher than that of TR90. This can be attributed to the nature of the tested membranes. The NF270 membrane has more opened pores compared to the NF90 membrane.

Figures 5 to 7 give respectively the characteristics of the permeate water and their salt rejection versus pressure obtained by NF90 and NF270.

The results show that at fixed salinity, the contents of all parametrs decreases with the applied pressure for each membrane. These results can be attributed essentially to the increase in the solvent flow.

Respectively, as can be seen, with increasing pressure, the salt rejection of all parametrs increases slightly, this can be explained by the influence of the pressure on the permeate flux (Figure2).

However, the highest rejections are obtained for the NF90 membranes, this result can be explained by the structure of the membrane which has properties close to RO membrane. In the case of NF, the selectivity is based on chemical phenomena, the pore size effect and the charge effects can influence the selectivity depending on the operating conditions and on the kind of NF membrane. The low value of rejection is given by the NF270 membrane with the value, these results can be explained by the mechanism transport depending only of the kind of membrane but the diffusion can be neglected.

Thus, in the case of NF90 the permeate quality is satisfactory for each applied pressure, all parametrs are lower than the standards recommended by WHO, but for NF270, the satisfactory water quality is occurs at a pressure of 10 bars.
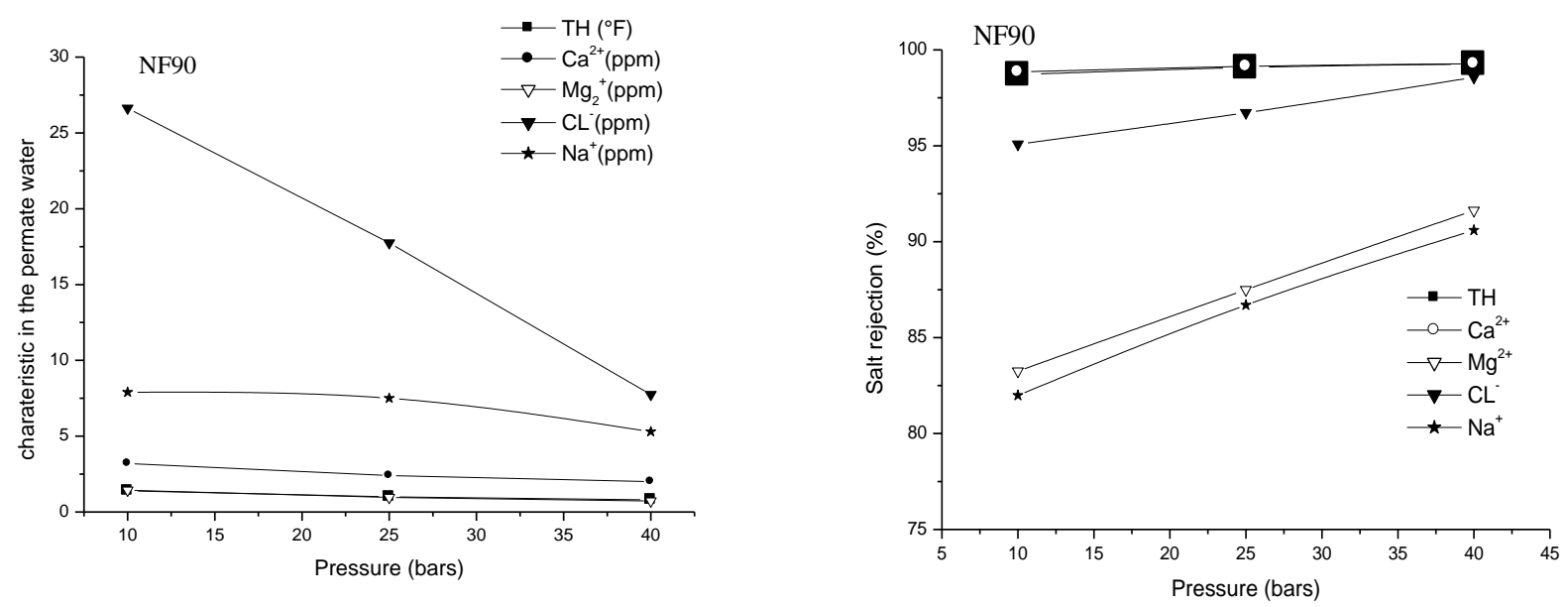

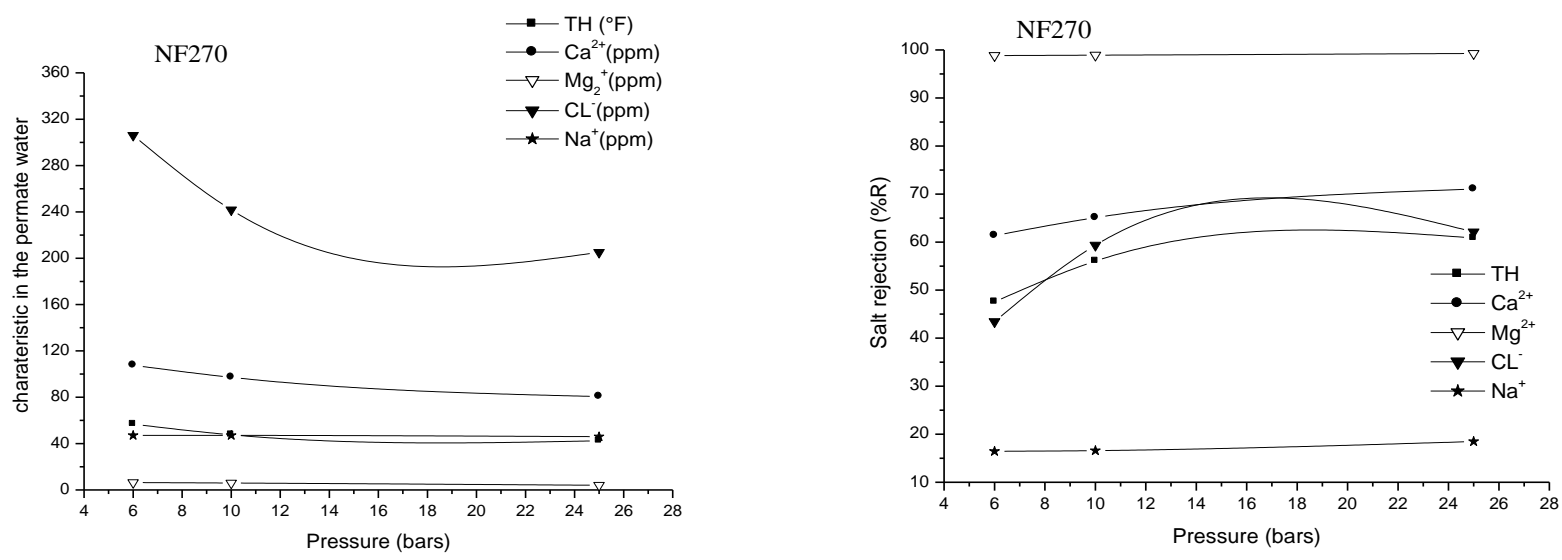

Figure 5: Variation of the permeate water characteristics and their salt rejection versus pressure of NF90 and NF270 for FW1.
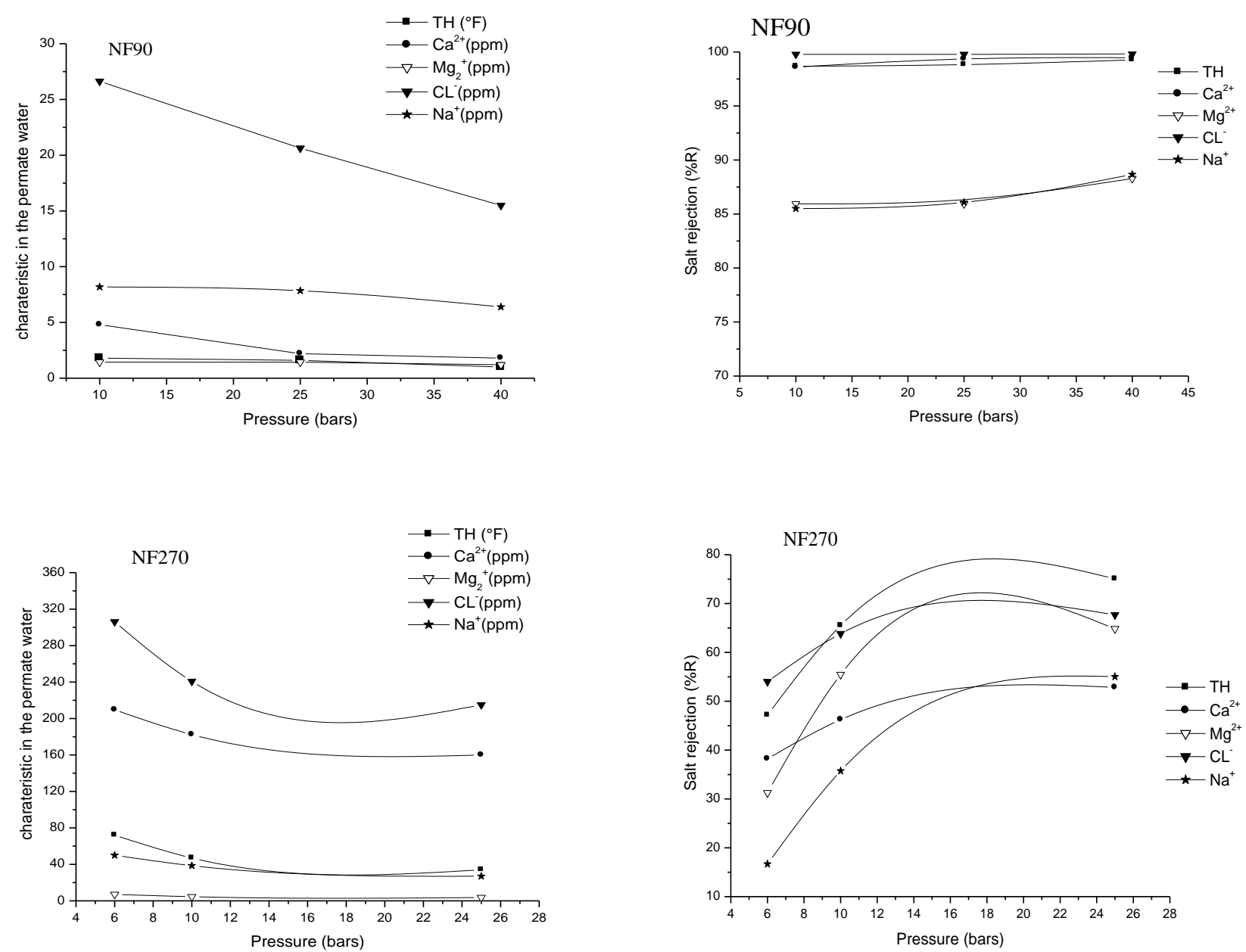

Figure 6: Variation of the permeate water characteristics and their salt rejection versus pressure of NF90 and NF270 for FW2. 

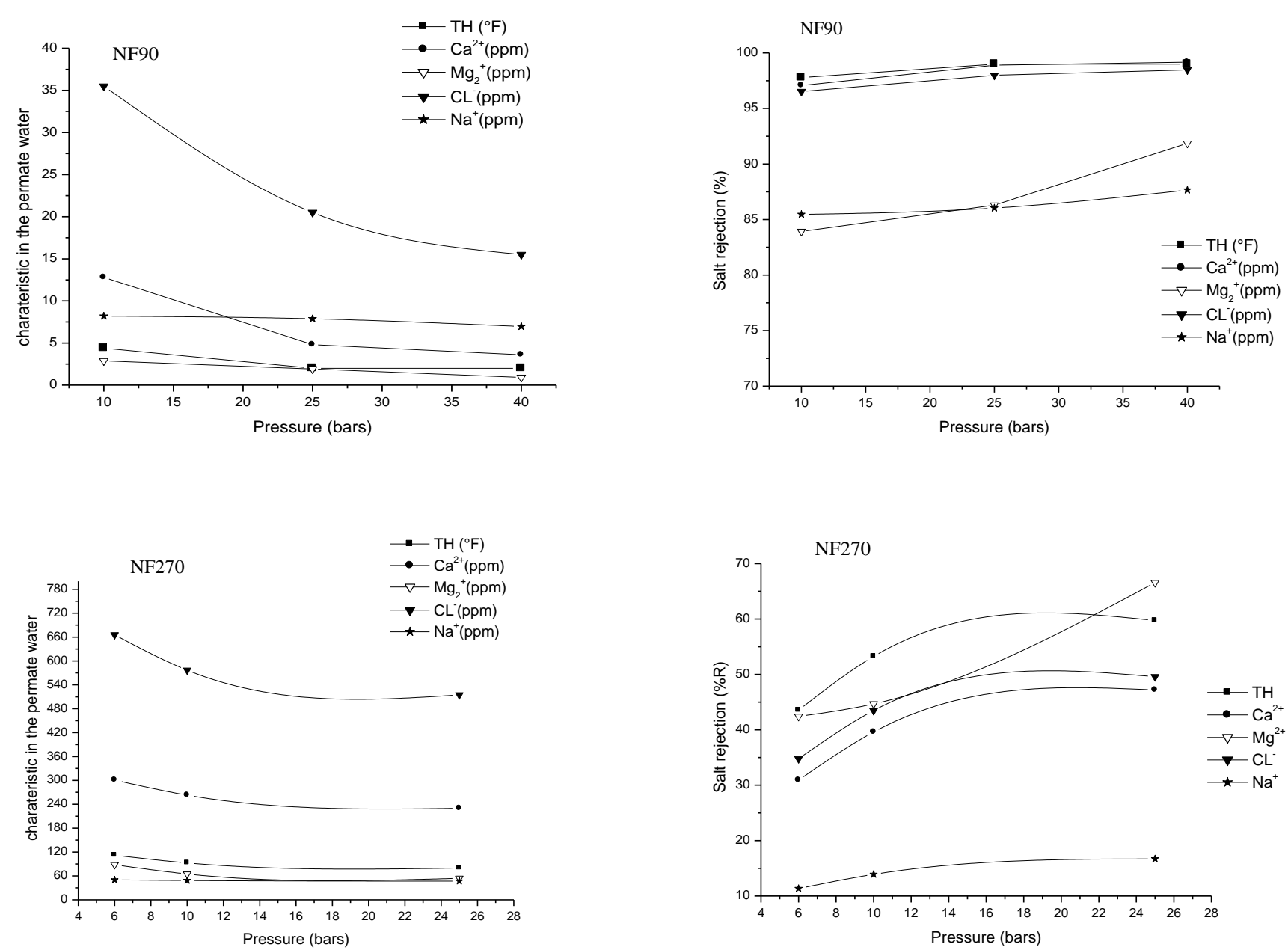

Figure 7: Variation of the permeate water characteristics and their salt rejection versus pressure of NF90 and NF270 for FW3.

\subsection{Effect of salinity}

A comparison of the performances of two commercial nanofiltration membranes in hardness removal was carried out in simple pass configuration. The applied pressure was 10 bars. The total flow for the two modules was 767 l/h for NF90 and 15561/h for NF270 corresponding respectively to a recovery rate of $37 \%$ and $57 \%$. The operations were conducted for various initial hardness contents of the feed water: 80,100 and $150^{\circ} \mathrm{F}$.

Figure 8 shows the variations as a function of the initial hardness content of the permeate hardness concentration for the two nanofiltration membranes tested.

Tables 3, 4 and 5 give the characteristics of the permeate for the two tested membranes and for three concentration of hardness.

Table 3: Characteristics of the permeate for FW1.

\begin{tabular}{lllll}
\hline $80^{\circ} \mathrm{F}$ & NF90 & & NF270 & \\
\hline Parametrs & Content & R\% & Content & R\% \\
Cond $(\mu \mathrm{S} / \mathrm{cm})$ & 38 & 97.88 & 929 & 48.19 \\
$\mathrm{TH}\left({ }^{\circ} \mathrm{F}\right)$ & 1.40 & 98.71 & 40.6 & 66.06 \\
$\mathrm{Ca}^{2+}(\mathrm{ppm})$ & 3.4 & 98.78 & 137.2 & 50.72 \\
$\mathrm{Mg}^{2+}(\mathrm{ppm})$ & 1.44 & 81.25 & 4.36 & 43.23 \\
$\mathrm{Cl}(\mathrm{ppm})$ & 26.63 & 95.08 & 221.75 & 59.04 \\
\hline
\end{tabular}




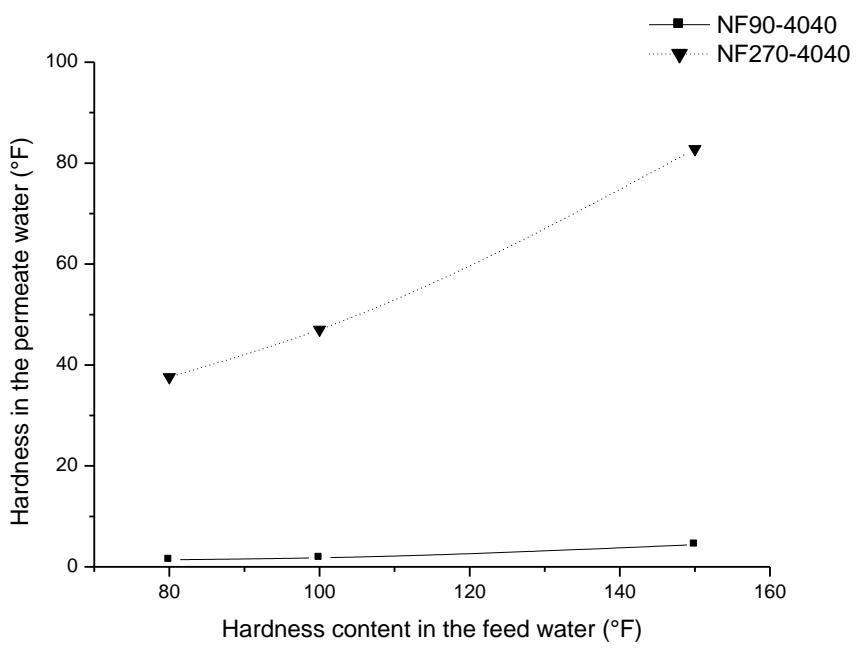

Figure 8: Hardness content in the permeate

Table 4: Characteristics of the permeate for FW2.

\begin{tabular}{lllll}
\hline $100^{\circ} \mathrm{F}$ & NF90 & & NF270 & R\% \\
\hline Parametrs & Content & R\% & Content & 35.58 \\
Cond $(\mu \mathrm{S} / \mathrm{cm})$ & 70 & 96.10 & 1155 & 65.50 \\
$\mathrm{TH}\left({ }^{\circ} \mathrm{F}\right)$ & 1.8 & 98.68 & 47 & 46.23 \\
$\mathrm{Ca}^{2+}(\mathrm{ppm})$ & 4.80 & 98.58 & 182.4 & 45.70 \\
$\mathrm{Mg}^{2+}(\mathrm{ppm})$ & 1.44 & 85.94 & 5.56 & 63.87 \\
$\mathrm{Cl}^{-}(\mathrm{ppm})$ & 30.63 & 95.40 & 240.5 & \\
\hline
\end{tabular}

Table 5: Characteristics of the permeate for FW3.

\begin{tabular}{lllll}
\hline $150^{\circ} \mathrm{F}$ & NF90 & & NF270 & R\% \\
\hline Parametrs & Content & R\% & Content & 45.67 \\
Cond $(\mu \mathrm{S} / \mathrm{cm})$ & 101 & 96.69 & 1657 & 58.27 \\
$\mathrm{TH}\left({ }^{\circ} \mathrm{F}\right)$ & 4.4 & 97.78 & 82.8 & 39.57 \\
$\mathrm{Ca}^{2+}(\mathrm{ppm})$ & 1.8 & 99.59 & 263 & 44.64 \\
$\mathrm{Mg}^{2+}(\mathrm{ppm})$ & 2.88 & 83.93 & 9.92 & 43.48 \\
$\mathrm{Cl}^{-}(\mathrm{ppm})$ & 35.5 & 96.52 & 576.87 & \\
\hline
\end{tabular}

The analysis of the results shows that:

The permeate quality obtained with the NF90 membrane is satisfactory in terms of hardness for three tested feed water. However, the water produced by NF90 are virtually demineralized hence the need for a post remineralization. Practically all the parametrs waters were much lower than the standards. These results can be attributed to the nature of this membrane which has properties close to RO membrane.

Therefore, the NF270 to be able the produce drinking water with satisfactory hardness content for feed water FW1 and FW3, but for FW3 the NF270 cannot provide to produce the drinking water, an additional treatment is necessary to bring back the contents of hardness to the standards.

For higher levels in the permeate quality achieved by NF270 of FW3 in terms of hardness, chloride at any tested conditions, other configurations were tested to reduce content to acceptable values. The operations were conducted with the initial hardness content of $150\left({ }^{\circ} \mathrm{F}\right)$. The configurations were double pass with one type of membrane NF270 and simple pass with a combination of NF270 with NF90. The tests were carried out under the same conditions of pressure (10 bars). Table 6 gives the composition of the permeate in the tested configurations.

The analysis of the results shows that, the highest rejections are obtained for the combination NF270/NF90 membrane. This result can be explained by the selectivity of membrane, it is not only based on chemical phenomena, but the pore size effect and the charge effects can influence the selectivity depending on the operating conditions and on the kind of NF membrane. 
However, the water quality was improved by the two configurations. The quality of the water produced is satisfactory, all parametrs water was significantly reduced and remained lower than the standards recommended by WHO. Although, the permeate water obtained by combination N270/NF90 required the post reminéralisation because the levels of all concentrations in the permeate was much less than the standards values.

\begin{tabular}{|c|c|c|c|c|}
\hline \multirow[b]{2}{*}{ Parametrs } & \multicolumn{2}{|c|}{ Combination NF270/NF90 } & \multicolumn{2}{|c|}{ Double pass NF270 } \\
\hline & Content & $\mathrm{R}(\%)$ & Content & $\mathrm{R}(\%)$ \\
\hline Conductivity $(\mu \mathrm{S} / \mathrm{cm})$ & 736 & 75.87 & 1055 & 65.41 \\
\hline Turbidity (NTU & 00 & 100.00 & 00 & 100.00 \\
\hline $\mathrm{pH}$ & 6.61 & ---- & 6.78 & $\begin{array}{ll}------ \\
\end{array}$ \\
\hline TDS (ppm) & 552 & 75.87 & 891.25 & 61.04 \\
\hline Hardness $\left({ }^{\circ} \mathrm{F}\right)$ & 36.4 & 81.65 & 45.8 & 76.35 \\
\hline $\mathrm{Ca}^{2+}(\mathrm{ppm})$ & 3.6 & 99.17 & 109.2 & 74.91 \\
\hline $\mathrm{Mg}^{2+}(\mathrm{ppm})$ & 8.8 & 50.89 & 18.4 & 41.96 \\
\hline $\mathrm{Na}^{+}(\mathrm{ppm})$ & 37.60 & 33.33 & 36.73 & 34.88 \\
\hline $\mathrm{SO}_{4}{ }^{2-}(\mathrm{ppm})$ & 3.20 & 94.67 & 3.4 & 94.33 \\
\hline $\mathrm{Cl}^{-}(\mathrm{ppm})$ & 19.63 & 98.08 & 213.88 & 79.04 \\
\hline $\mathrm{NO}_{3}^{-}(\mathrm{ppm})$ & 21.20 & 48.29 & 20.40 & 39.83 \\
\hline
\end{tabular}

\section{Conclusion}

In this work, studies on the hardness removal by nanofiltration were conducted on underground water of Maâmoura .The comparison of the performances of two membranes tested in hardness removal by nanofiltration in continuous mode was carried out:

- The quality achieved by NF90 is satisfactory, all parametrs are below much the range accepted by WHO. A remineralization step is required.

- The properties of NF90 membranes are close to RO membranes.

- The NF270 membrane has more opened pores compared to the NF90 membrane

Following the initial fluoride content various configurations were tested:

- For equilibrated water and for the initial hardness content lower than $100 \mathrm{ppm}$, it is preferable to use the simple pass configuration with NF90 or NF270.

- For equilibrated water and for the initial hardness content higher than $100\left({ }^{\circ} \mathrm{F}\right)$, it is preferable to use the double pass with NF270 or, the simpl pass with combination NF270/NF90 or NF90.

In the concentration range of the treated water studied, practically all the parameters of the water quality are ameliorated by the NF operation especially the water salinity.

\section{Acknowledgements}

This work was supported by TIA Company France. The authors express their thanks for this support.

\section{References}

[1] N.; Kabay, M.; Demircioglu, E. Ersöz, I.; Kurucaovali, Removal of calcium and magnesium hardness by electrodialysis. Desalination 149 343-349, 2002

[2] A Bannoud,. Elimination de la dureté et des sulfates contenus dans les eaux par nanofiltration. Desalination 137 (2001) $133-139$

[3] W. J. Conlon,; C. D.; Hornburg, , B. M. Watson; C. A. Kiefer,; Membrane softening: the concept and its application to municipal water supply,Desalination, 78, 157, 1990.

[4] D.L.; Comstock, Desal-5 membrane for water softening, Desalination, 76, 61, 1989.

[5] L.P. Raman; M.; Cheryan, N. Rajagopalan, Consider nanofiltration for membrane separation.Chem. Eng. Prog. 1994, 90, 68-74.

[6] P. Eriksson, Nanofiltartion extends the range of membrane filtration. Environ. Prog., 7,58-61, 1988.

[7] J. Schaep,; B. van der Bruggen,; S Uytterhoeven,.; R. Croux,; C. Vandecasteele,; D. Wilms,; E. van Houtte; F Vanlerberghe,. Removal of hardness from groundwater by nanofiltration. Desalination, 119, 295-302, 1998. 
[8] A Gorenflo; D. Velazquez-Padron,; F.H. Frimmel, Nanofiltration of a German Goundwater of high hardness and NOM content: Performance and coast. Desalination, 151, 253-265, 2002.

[9] S. Ghizellaoui,; S.; Taha, G.; Dorange, A. Chibani,; J Gabon,. Softening of Hamma drinking water by nanofiltration and by lime in the presence of heavy metals. Desalination 171, 133-138, 2004.

[10] C.M. Galanakis,; G.; Fountoulis, V. Gekas, Nanofiltration of brackish groundwater by using a polypiperazine membrane. Desalination, 286, 277-284, 2012.

[11] F. Elazhar; N. El Harrak,. Z. Abedelali, M, El Amrani., M.Taky., A Elmidaoui., Technical and economical comparison of the nanofiltration and reverse osmosis membranes in the brackish water desalination, Chemical technology, An Indian Journal, 7, pp 29-33, 2012

[12] F. Elazhar; M Elamrani., M, Taky. M, Hafsi. A Elmidaoui. Performances of nanofiltration and reverse osmosis membranes in desalination of M'nasra Brackish water: Comparison under running conditions, International Journal of Environmental Sciences Volume 3 No.2, 2013

[13] A. El midaoui; M.A.M., Sahli .M. Tahaikt,. L., Chay M. Taky., M., Elmghari..M Hafsi. Selective nitrate removal by coupling electrodialysis and bioreactor, Journal of Desalination, 153, pp 389-397,2002.

[14] A. El midaoui.; F. Lutin.L; ; Chay M.; Taky.. M. Tahaikt; .My R. Aloui Hafidi Removal of melassigenic ions for beet sugar syrups by electrodialysis, Journal of Desalination, 148, pp 143-148, 2002. 